\title{
磁気研磨ブラシによる研磨機構の解明
}

\author{
馬 雷*1, 古木 辰也*2, 呉 魏*3, 廣垣 俊樹*3, 青山 栄一*3
}

\section{Elucidation of the polishing mechanism by the magnetic polishing brush}

\author{
Lei MA*1 ${ }^{* 1}$, Tatsuya FURUKI ${ }^{* 2}$, Wei WU*3 ${ }^{* 3}$ Toshiki HIROGAKI ${ }^{* 3}$ and Eiichi AOYAMA*3 \\ ${ }^{*},{ }^{*}$ Department of Science and Engineering, Doshisha University \\ 1-3 TataraMiyakodani, Kyotanabe-shi, Kyoto 610-0394, Japan \\ ${ }^{* 2}$ Department of Engineering, Gifu University \\ 1-1 Yanagido, Gifu-shi, Gifu 510-1193, Japan
}

\section{Received 3 June 2016}

\begin{abstract}
Nowadays, a free-form surface, such as molding die surface, is required to be finished by reducing the environmental burden. Therefore, a novel polishing technology is needed with a less abrasive slurry,for the reduction of which a magnetic abrasive finishing method is attracting attention. However, it is well known that a conventional magnetic polishing method is unstable and insufficient to obtain the required surface roughness. In the present paper, we discuss the reasons causing instability in conventional magnetic polishing. We systematically investigate the magnetic pressure distribution characteristics and measure the pressing force distribution of the magnetic brush during machining. Furthermore, to observethe impact of an iron particle shape on the pressing force, we used steel balls (steel-ball brush) and abrasive slurry. Moreover, we compared this brush with a brush that uses iron powder paste (employed in the conventional magnetic polishing method). Thus, we determined the possibility of the wide range control of the pressing force by changing the shape and size of the magnetic material. The setting of the approach conditions should be sufficient because it could deteriorate the shape accuracy through very high pressure.
\end{abstract}

Key words : Polishing tool, Steel ball, Abrasive slurry, Particle brush, Polishing characteristics, Machining center

\section{1. 緒言}

磁気研磨ブラシとは，鉄粉と砥粒を油で混ぜた磁性研磨ペーストと先端に永久磁石を取付けた磁気研磨工具か らなり，磁気研磨工具に取付けられた永久磁石に磁性研磨ペースト中の鉄粉がブラシ状に付着したもので（進村 他，1986）(土屋他，1993）, 研磨剤自身が磁気によりブラシを形成するブラシ研磨の一種と考えることができる. そして，先端に球状の永久磁石を取り付けることにより，ボールエンドミル加工により仕上げられた自由曲面を 同じプログラムで研磨することができる．多軸マシニングセンタや加工ロボットとの統合によって，従来対応が 困難であった加工への応用が展開されつつある. 例えば, 精密容器のライニング, 石油およびガスパイプライン, リテーナベアリング油圧部品の各種バルブなどの分野でその役割を果たしている (Li et al., 2013) (Jayakumar et al., 1997）（川久保他，2014）.

これまでの磁気研磨法に関する研究は，表面あらさの改善に関するのが大半である（Sharma et al., 2015）。しか

No.16-00253 [DOI:10.1299/transjsme.16-00253], J-STAGE Advance Publication date : 22 November, 2016

${ }^{* 1}$ 正員, 同志社大学大学院 理工学研究科（广 610-0394 京都府京田辺市多々羅都谷 1-3）

*2 正員, 岐阜大学 工学部 ( $501-1193$ 岐阜県岐阜市柳戸 1-1)

*3 正員, 同志社大学 理工学部

E-mail of corresponding author: eup1506@mail4.doshisha.ac.jp 
し，砥石を用いた研磨加工の場合と同様，磁気研磨ブラシの押付け力（以下，ブラシ押付け力と呼ぶ）が加工特 性の大きな支配因子であると考えられる磁気研磨法（夏目，進村，2008）において，押付け力の特性と発生機構 に関してはほとんど検討されていない，実際，従来の磁性研磨ペース卜（強磁性材粒子と砥粒および溶媒から単 純に混合したもの）を用いて平面や曲面の仕上げ加工を行う場合, 研磨特性のばらつきが大きく, 形状精度の予 測ができないため，加工プロセスの最適化の設定が困難であった．そこで，本研究では，ボールエンドミル型の 磁気研磨工具とマシニングセンタを統合した自由曲面研磨加工の実用化を目的に，ブラシ押付け力を決定する因 子の検討を行った. マシニングセンタでのエンドミル加工においては, (1)工具を設定の切り込みまで被削材に近 づけていくアプローチと(2)形状を創生する形状加工とを区別して議論される場合が多い. 磁気研磨ブラシの場合, ブラシ押付け力は磁気研磨工具先端と被加工物までの法線方向距離（ギャップ： $\Delta n$ ）で管理されるのが一般的で ある. また, 磁気研磨ブラシのブラシと被加工物との接触状態（接触面積, 押付け力等）はアプローチ中に時々 刻々と変化し，アプローチ終了後に定常值に収束するものと考えられる．そこで本研究では，アプローチ中のブ ラシ押付け力や被加工物との接触状態の変化を観察することにより, 磁気研磨ブラシのブラシ押付け力の決定因 子を検討した.

本報では，非磁性体材料であるオーステナイト系ステンレス鋼とアルミ二ウム合金を用いて製作した磁気研磨 実験専用ジグを用い, 高速度カメラと動力計との組合せによる観察システムを構築し, 市販の磁性研磨ペースト を用いて磁気研磨加工のメカニズムを考察した，さらに，それらの結果より，真球の鋼球による鋼球磁気研磨ブ ラシを提案した．そして，市販の磁気研磨ブラシと比較することにより，ブラシ押付け力を制御して鏡面化と形 状誤差の僅少化を図る工程において重要な因子を検討した.

\section{2. 実験装置}

加工装置には図 1 に示す立型 3 軸制御マシニングセンタ ROBODRILL $\alpha$-T14 DSe（ファナック製，最小指令值： $1 \mu \mathrm{m}$ ） と磁気研磨工具 NPS-Ф6-Ф10-R5（FDK 製，工具先端ボール部半径 : $5 \mathrm{~mm}$ ）を用い，図 2(a)に示すように, 平面研磨加工を行った. また, 図 2(b)に示寸ように, 工具先端の球型強力ネオジウム永久磁石（磁場強さ: $0.5 \mathrm{~T}$, 直径：10 mm）は接着剤で磁気研磨工具の穴部と結合している.この永久磁石の磁力により形成された磁気研磨 ブラシ（＝磁石の磁力線に沿って吸着した磁性研磨ペースト中の鉄粉）から加工物に作用する押付け力は, 永久 磁石による磁場分布に大きく依存するため, 測定装置による磁場の変化を最小限にする必要がある. また, 市販 の動力計 9347C（KISTLER 社製 3 成分フォースリンク）は磁場分布に影響を与えるだけでなく, 磁場により計測 結果にも影響が出る. そこで図 3 に示すように動力計への磁場の影響を防ぐため, 磁気研磨実験専用の非磁性ジ グ（以下，専用ジグと呼ぶ）を製作した。

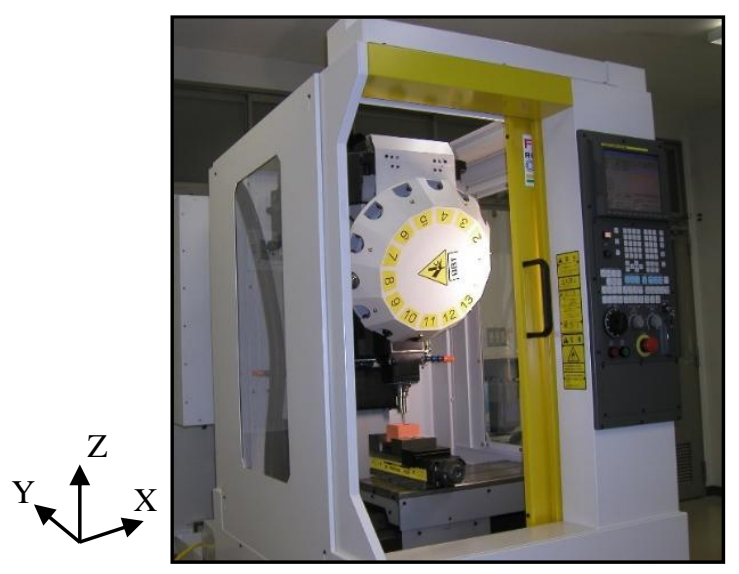

Fig.1 Vertical machining center.

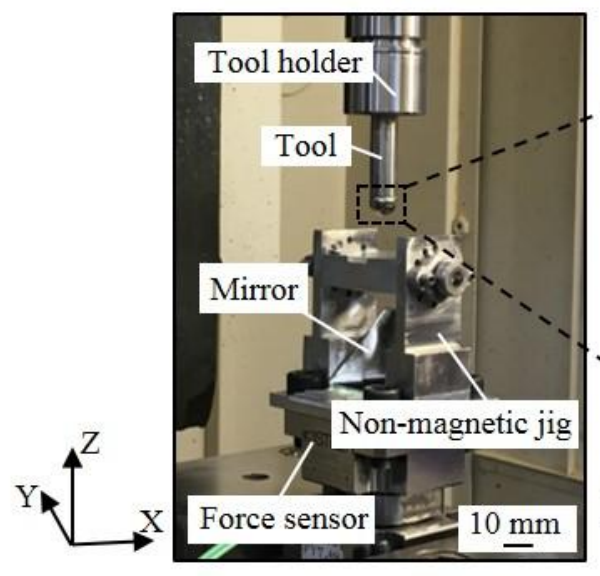

(a) Apperance of polishing

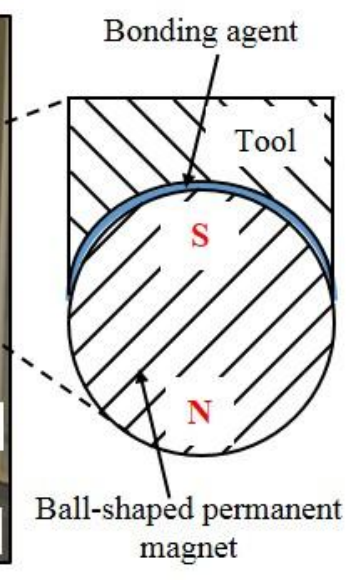

(b) Structure of tool tip

Fig.2 Experimental device. 
Ma, Furuki, Wu, Hirogaki and Aoyama, Transactions of the JSME (in Japanese), Vol.82, No.844 (2016)

1) 定位ピン（Fixed pin）とネジ付き固定ピン（Screw pin）により加工物を $\theta=0^{\circ}$ (=加工平面が鉛直)，30 ， $45^{\circ}, 60^{\circ}, 90^{\circ}$ (=加工平面が水平) の 5 種類の角度に傾斜できる.

2）非磁性のオーステナイト系ステンレス鋼とアルミ二ウム合金で製作したため, 磁気研磨工具の磁場の影響 を受けず押付け力の測定結果の再現性が高まる.

3) 加工物ホルダには直径 $26 \mathrm{~cm}$ の穴を開けているため, その下にミラーを角度 $\alpha=\theta / 2$ で設定し, 透明なアク リル板やガラス板を被加工材とすることで，磁気研磨ブラシの挙動（被加工材との接触領域）を動画撮影 することができる（図 3 の右下図参照).


Fig. 3 Design of special jig.

将来，自由曲面の磁気研磨自動化を実現するために，各傾斜面に沿つて磁気研磨ブラシの加工特性を観察する ことができる．ただし本報では，加工物上面が水平状態 $\left(\theta=90^{\circ}\right)$ の場合の観察を以後の対象とする（図 3 の右 上闵参照).

今までの多くの研究では磁性粒子の作用と研磨面との関係を解明するため，垂直力測定装置に工夫を重ね，そ れなりの成果（夏目，進村，2008）をおさめてきたが，さらに，磁気研磨ブラシの加工物表面上での振る舞いを 直接観察できれば，より詳細な現象の解明が期待できる。そこで，この専用ジグを介して磁気研磨ブラシの押付 け力と磁気研磨ブラシの挙動とを同時に観察する手法を開発した。(図 4)


Fig. 4 Schematic of recording by a high-speed camera and a force sensor.

ビデオ画像より各フレームの全画素輝度合計值を輝度加算值として計算し，その時間的変化を示した図をモー
(戍 4 右下) と呼ぶ, 輝度值によりビデオ画像の時間的変化を数值化したものと考えることができ る.本実験においては, 透明なアクリル板加工物表面と磁気研磨ブラシの接触部分の輝度值の変化が大きいため, 接触面積の時間的変化を近似的に評価するための指標とした。 また，図 4 に示すように, KENYENCE 製の VW 
-9000 高速カメラ（1 チャンネルのデータロガー内蔵）に，動力計からのアナログ電圧信号を入力することがで きる. そのアナログ電圧信号を押付け力へ変換して動画との同期表示（図 4 右）させることによって磁気研磨ブ ラシの加工特性を詳細に観察できる。この観察方法により研磨特性の主たる支配因子である押付け力の特性と押 付け力の発生機構を系統的に明らかにすることが期待できる.

\section{3. 市販の磁性研磨ペーストによる研磨特性の解明}

\section{$3 \cdot 1$ 磁気研磨ブラシの挙動}

磁気研磨加工法については加工圧制御に関して不明な部分が多い，そこで，平面形状の工作物に対して，磁気 研磨工具を設定ギャップ（磁気研磨工具先端と加工平面とのギャップ $\Delta n$ の目標值）までアプローチ（本研究で は被削材表面に対して垂直に工具を近づけた）する間の磁気研磨ブラシと工作物の接触状態と押付け力との関係 に注目した. 寸なわち, 磁気研磨ブラシを構成する磁性研磨ペースト中の磁性粒子の分散性, 凝集性を観察した。



(a) $t=0 \mathrm{~s}, \Delta \mathrm{z}=8.7 \mathrm{~mm}$



(f) $t=29.4 \mathrm{~s}, \Delta \mathrm{z}=0.3 \mathrm{~mm}$



(b) $t=4.0 \mathrm{~s}, \Delta \mathrm{z}=7.5 \mathrm{~mm}$
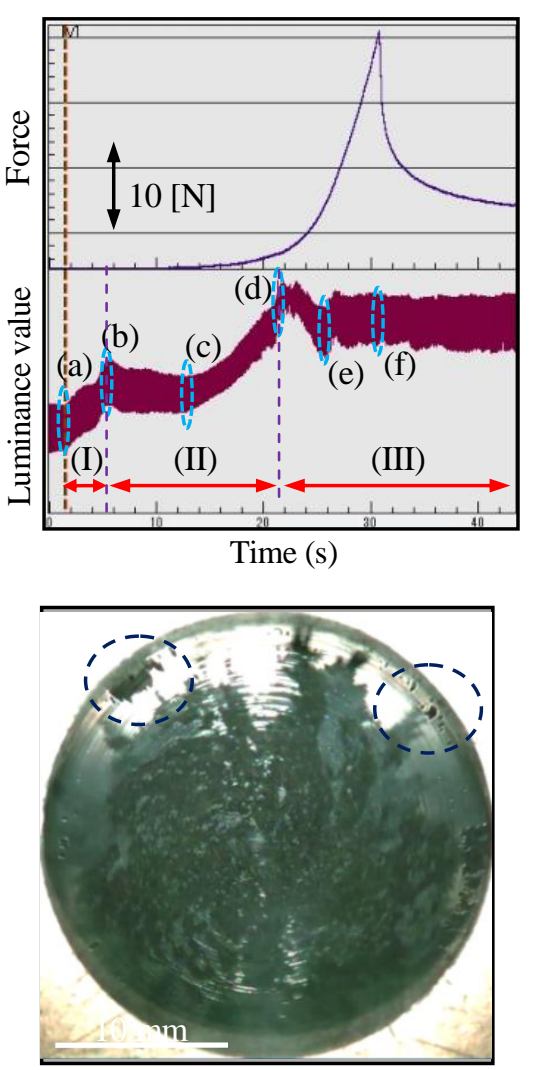

(e) $t=24.4 \mathrm{~s}, \Delta \mathrm{z}=1.5 \mathrm{~mm}$

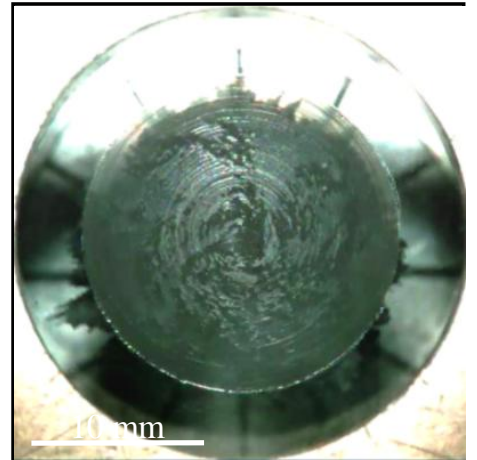

(c) $t=11.6 \mathrm{~s}, \Delta \mathrm{z}=5.1 \mathrm{~mm}$

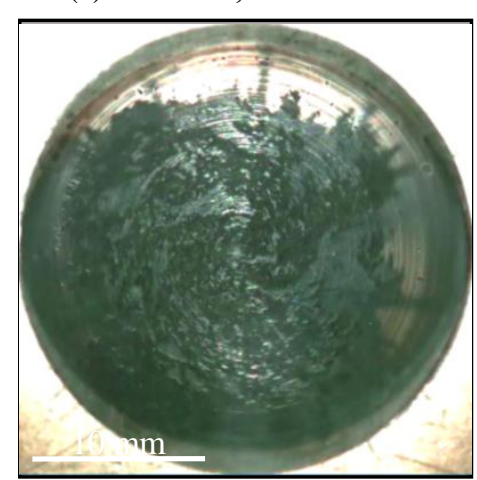

(d) $t=20.4 \mathrm{~s}, \Delta \mathrm{z}=2.7 \mathrm{~mm}$

Fig.5 Variation of pressing force of commercial polishing paste with times. 
本実験では，磁性研磨ペーストに A 社製の磁性研磨ペースト（鉄粒子，粒径：1～100 $\mu \mathrm{m}$ ，アルミナ砥粒，粒 径 : $0.05 \mu \mathrm{m}$ および植物油からなる）を使用した. まず, 工具回転数 $S=750 \mathrm{~min}^{-1}$, アプローチ速度（工具アプロ 一チ時の加工物平面への法線 $n$ 方向送り 速度) $f_{\mathrm{n}}=18.0 \mathrm{~mm} / \mathrm{min}$, 設定ギャップ (磁気研磨工具先端と加工平面との ギャップ $\Delta n$ の目標值） $\Delta n s=0.3 \mathrm{~mm}$ (ベースト中の鉄粒子の最大径の約 3 倍とした), 磁性研磨ペースト量 $w=3 \mathrm{~g}$ の研磨条件でアクリル板（直径 : $30 \mathrm{~mm}$, 厚さ : $3 \mathrm{~mm}$ ）を加工物としてアプローチ加工実験を行った. また, 計 測は開発した観察装置により，高速カメラ（シャッタースピード : 1/2000 sec, フレームレート： $500 \mathrm{fps）による}$ 磁気研磨ブラシ接触状態と動力計による押付け力を同時に観察した。本実験では，ギャップ $\Delta n=10.0 \mathrm{~mm}$ からス タートし, 設定ギャップ $\Delta n s=0.3 \mathrm{~mm}$ に達して送りを停止した後, 押付け力が安定するまで観察を行った. その結 果を図 5 に示す.

図 5 中央のモーショングラフと各ビデオ画像より, 磁気研磨ブラシ接触状態の時間的変化は, (I) $t=0 \sim 4$ 秒（図 5(a) (b))，（II） $t=4 \sim 20$ 秒（図 5(b) (d)）とそれ以降（III）の3つの領域に大別できることが分かる.（I）の領域で は磁気研磨ブラシが加工物表面上で工具回転中心（図 5(a)のクロス破線参照）より半径方向に少し離れたところ から接触がスタートして環状に拡大寸る。この領域ではモーショングラフ（接触面積に対応）は急激に増加して いる.しかし，押付け力はほとんど変化していない（II）の領域では磁気研磨ブラシ中心部が接触し，接触領域 は外側に拡大し. モーショングラフの值も指数関数的に増加する. しかし, 押付け力の増加は緩やかである. (III) は接触が一定となる領域である.この領域では押付け力は指数関数的に急激に増加する. 領域（II）までは磁気 研磨ブラシは工作物表面内での変形が主体であり, 領域（III）では工作物表面法線方向の変形が主になるため押 付け力が急増したものと考えられる.また, 磁気研磨工具が設定ギャップ位置に到達する(f)において押付け力が 最大值に達し，送りが停止した状態で押付け力は指数関数的に定常值に収束寸る. これは磁気研磨ブラシが粘弾 性的な性質を持つことを示している．また，ビデオ画像（図 5(d)〜(f)）より，磁気研磨ブラシは円形に一様に分 布せずに，不均一・非定常に偏在していることが分かる．これが磁気研磨ブラシの研磨特性にばらつきが出る一 つの要因と考えられる．また，各領域ともモーショングラフの縦軸方向の線幅が太くなっている．これは接触領 域の時間的変動が大きいためである.また, 磁気研磨ブラシから分離した磁性粒子のかたまりが観察される（図 5(e)赤破線部分参照)。これは磁気研磨ブラシが加工物表面上の過大な摩擦力（接線方向力）を受けたことが原因 であると考えられる．この分離磁性粒子は再び磁気研磨ブラシに結合し，分離，結合を繰り返す．

磁気研磨ブラシが加工物に近づく際の変形特性を調べるために, 磁気研磨ブラシによる押付け力の変化を詳細 に検討した. その結果を図 6 に示寸. 図 6 よりアプローチ中, 磁気研磨ブラシの押付け力は指数関数的に増加し, 設定值に達した時点で最大值 $F_{\max }$ となり，その後送りが停止した状態で時間とともに指数関数的に定常值（図 6 中の $F_{\text {sta }}$ ) に収束する粘弹性的な現象を示すことが分かる. この残留する定常押付け力が研磨加工時の押付け力 となる. 市販磁性研磨ペーストでは, 最大押付け力 $F_{\max }=$ 約 $30 \mathrm{~N}$, 定常押付け力 $F_{\mathrm{sta}}=$ 約 $15 \mathrm{~N}$ であり, アプローチ 中の押付け力の最大值は定常値の 2 倍あり, アプローチ条件の設定には注意が必要である.



Fig. 6 Variation of pressing force of commercial polishing paste and Gap. 


\section{$3 \cdot 2$ 切りくずと仕上げ面性状の観察}

磁気研磨法において, 高能率を達成している磁気研磨ブラシの研磨メカニズムについて検討するため, 非磁性 金属の中で柔らか目の黄銅（C3604，ビッカース硬度 412 519 HV）を加工物とし，設定ギャップ $\Delta n s=0.3 \mathrm{~mm}$ で 加工平面に平行な方向 (図 $8(\mathrm{a})$ の $\mathrm{X}_{1}$ と $\mathrm{X}_{2}$ の間) に送り運動を加えて 30 分間 (送り速度 $f_{\mathrm{x}}=10.8 \mathrm{~mm} / \mathrm{min}, 10$ 往復) の平面研磨実験を行った. 加工後, 磁性研磨ペーストを回収し, 乾燥した後に永久磁石で Fe 粒子を除去した後, SEM による観察とX 線マイクロアナライザーによる元素分析を行った。 その結果を図 7 に示す.

図 7(a)の SEM による観察視野内で切削作用により除去されたと思われる切りくず状のものが確認できた. その 中で最も大きい切りくず状のものは幅 $0.4 \mu \mathrm{m}$, 長さ $6 \mu \mathrm{m}$ 程度であった. そこで，この切りくず状のものの元素 分析を行うと加工物の主要成分である $\mathrm{Cu}$ が検出された（図 7(b)).アルミナ砥粒のサイズ（粒径 $0.05 \mu \mathrm{m} ）$ を考慮 すると，この切りくず状のものは鉄粒子のエッジによる切削作用により生じた切りくずであることが分かった.

次に，加工した加工物の表面性状を評価するために，表面光沢度 $G r$ および断面曲線を採用した．表面光沢度 Gr の測定には，グロスチェッカーIG-410（堀場製作所製）を使用した．表面性状はボールエンドミルによる前加 工面の切削痕が除去され，表面光沢度 $G r$ が 90\%以上の場合を鏡面とした（古木他，2014）。本実験で測定した加 工物の表面光沢度は $G r=92.2 \%$ あり，加工した加工物の表面は鏡面になることがわかった．また，断面曲線の 測定には，触針式表面粗さ測定器（小坂研究所製の SE-30C，触針先端半径 $2 \mu \mathrm{m}$ ）を利用した. その結果を図 8 に示す.



(a) SEM photo

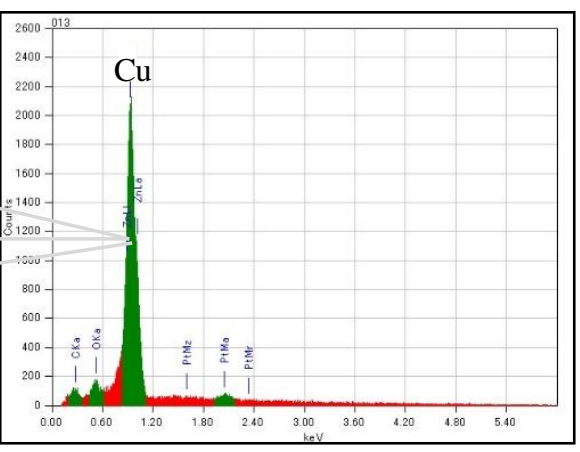

(b) Energy dispersive analysis

Fig. 7 Element analysis of polishing chips.

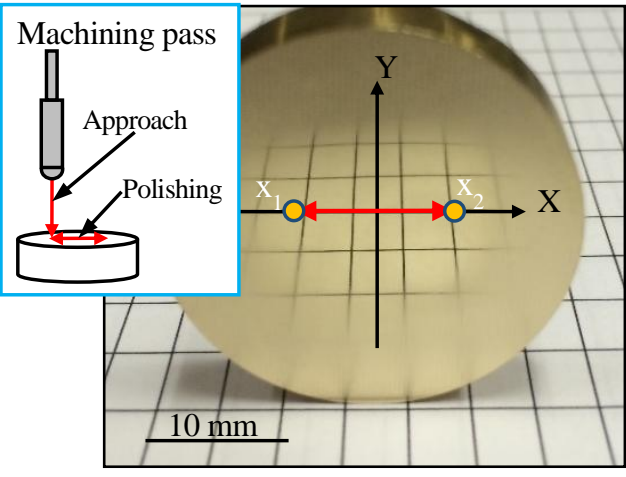

(a) Photograph of polished workpiece

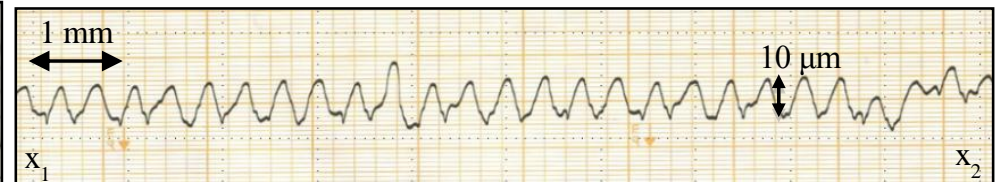

(b) Before finishing

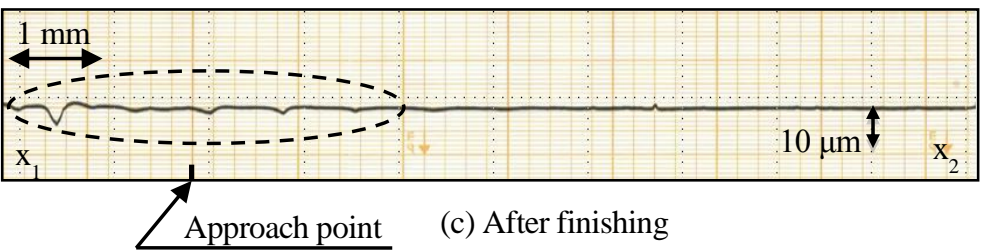

Fig. 8 Section curves obtained before and after finishing.

上述したように，ボールエンドミルの前加工面の切削痕（図 8(b) : 最大粗さ $10 \mu \mathrm{m}$ 程度）は磁気研磨によって 図 8(a), (c)に示すように平滑な鏡面に仕上がっている. その一方で，図 8(a)の加工物の中心より左側（ $x_{1}$ 側）にお いて，図 8(c)の点線で囲む断面曲線部分がみだれていることから，いわゆる鉄粒子のエッジによる切削作用によ り平面度がくずれたこともわかる。この部分は磁気研磨工具のアプローチ位置に対応しており，アプローチ中の 過大な押付け力により大きな切りくずを生成したためと考えられる.

以上の結果より，市販磁性研磨ペーストを用いて磁気研磨加工を行う場合には，鉄粒子のエッジによる切削加 工とアルミナ砥粒による研磨加工が混在した加工であるため, バフ研磨よりも高能率な研磨を実現していること 
がわかった. しかし，最大粗さ $10 \mu \mathrm{m}$ 程度の粗い加工から加工能率よく中仕上げレスで最終仕上げとして鏡面を 得ることができる一方で, 制御不能な鉄粒子のエッジによる切削作用も混在し，ムラなく再現性のよい仕上げ加 工をするには課題の残ることがわかった.

\section{4. 鋼球磁気研磨ブラシによる磁気研磨法}

磁気研磨ブラシの加工表面での分布の不均一性は，研磨能率の安定性を崩すばかりでなく，加工面品質に大き な影響を及ぼすことがわかった。つまり加工欠陥の発生の原因になる（河西, 安永, 2010).上述の市販磁性研磨 ペーストにおいて，鉄粒子の形状が不規則で凹凸が大きく，磁性粒子間の相対移動が表面の凹凸により妨げられ るため困難となり，磁気研磨ブラシの分布に不均一性が発生したものと考えられる. すなわち，鉄粒子の形状が 磁気研磨ブラシから加工物に作用寸る押付け力の分布に大きく影響寸ることが考えられる. そこで, 真球度が高 く凹凸の無い鋼球によるブラシを作製し，この鋼球磁気研磨ブラシと市販磁気研磨ブラシを比較することで鉄粉 形状の研磨能力に及ぼす影響を検討した。

鋼球磁気研磨ブラシの概略図とその写真を図 9 に示す。提案した鋼球磁気研磨ブラシの磁性研磨ペーストは, 鋼球とスラリーで構成されている. 鋼球は, ベアリング用鋼球（高炭素クロム軸受鋼 SUJ2, $\Phi 0.35 \mathrm{~mm}$, 真球度

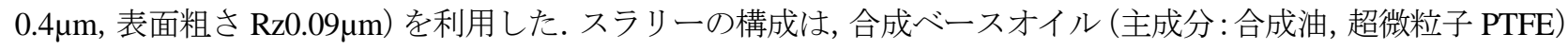
とアルミナ砥粒から成る.

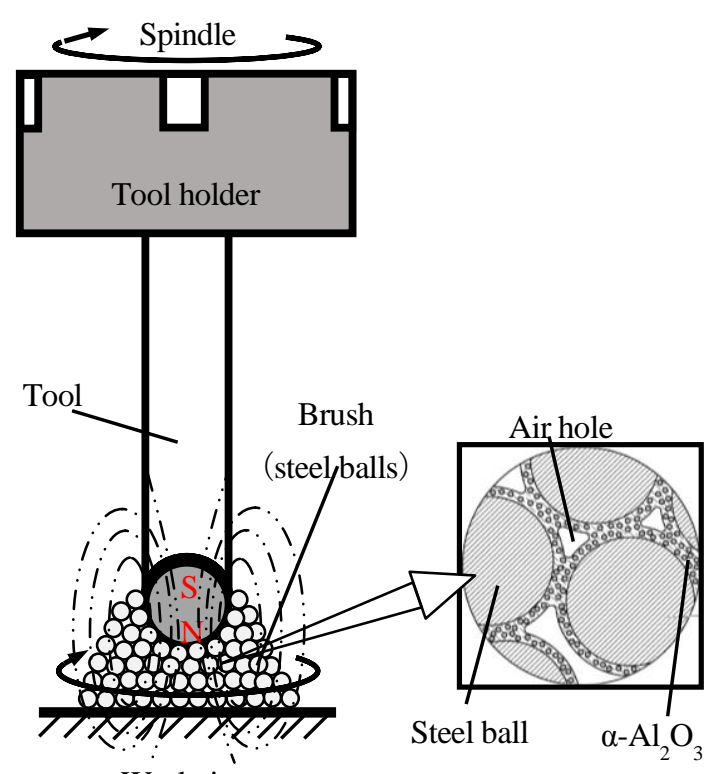

Workpiece



(b) Steel balls brush

(a) Model of polishing tool

Fig. 9 Concept of magnetic polishing tool.

\section{5. 鋼球磁気研磨ブラシによる押付け力特性の解明}

\section{$5 \cdot 1$ 磁性研磨ペーストの構成}

本実験では, 磁気研磨ブラシを形成する磁性研磨ペースト中の鉄粉形状の影響を考察するために, 真球度の高 い鋼球を用いた磁性研磨ペーストを作成し，鋼球磁気研磨ブラシによる押付け力の特性を実験により求めた。ま た，市販磁気研磨ブラシと比較することで，鉄粉形状の影響と押付け力発生機構を検討した．鋼球磁性研磨ぺー ストの構成成分の質量％と詳細を表 1 に示す．また，SEM で鋼球表面を観察した結果を図 10 に示す. 図 10 に示 した 2 次電子像より, WA 砥粒 $\left(\alpha-\mathrm{Al}_{2} \mathrm{O}_{3}\right.$, ビッカース硬度 1900 2100 HV) が鋼球 (SUJ2, ビッカース硬度 760 840 HV）表面上に付着していることがわかる. 
Table 1 Composition of model paste.

\begin{tabular}{c|c}
\hline Brush & Steel balls ( SUJ2, $\Phi 0.35 \mathrm{~mm}), 70 \mathrm{wt} \%$. \\
\hline \multirow{3}{*}{ Slurry } & $\begin{array}{c}\text { WAabrasives }\left(\alpha-\mathrm{Al}_{2} \mathrm{O}_{3}, \quad 1.0 \mu \mathrm{m}\right), 7 \mathrm{wt} \% \\
\text { Lubricating oil (PTFE) }: 118 \sim 122 \mathrm{cSt}\left(40{ }^{\circ} \mathrm{C}\right) \\
14 \sim 17 \mathrm{cSt}\left(100^{\circ} \mathrm{O}\right), 23 \mathrm{wt} \% .\end{array}$ \\
\hline
\end{tabular}

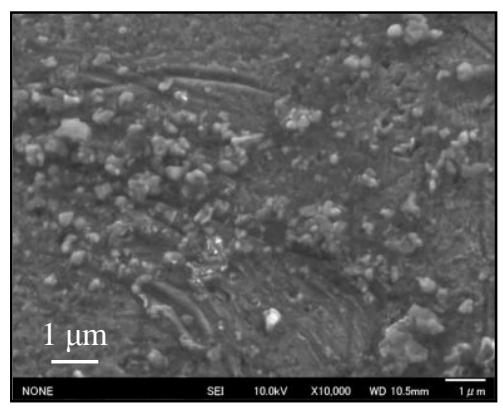

Fig. 10SEM photograph of steel ball surface.

\section{$5 \cdot 2$ 実験条件と鋼球磁気研磨ブラシの挙動}

直径 $\Phi 30 \mathrm{~mm}$, 厚さ $3 \mathrm{~mm}$ のアクリル板を加工物とし，2 章で述べた観察手法によって加工中の鋼球磁気研磨ブ ラシの挙動と押付け力の変化を同時に記録した. 実験条件は, 工具回転数 $S=750 \mathrm{~min}^{-1}$ とし, 設定ギャップが $\Delta n s=$ $1.0 \mathrm{~mm}$ (=鋼球直径の約 3 倍程度 $)$ となるまで, 3.1 節と同様の手順でアプローチ中 $\left(\Delta n=10.0 \mathrm{~mm}\right.$ より $f_{n}=18.0 \mathrm{~mm} / \mathrm{min}$ で加工面にアプローチし,$\Delta n=1.0 \mathrm{~mm}$ に達した時点で送りを停止, その後の様子も観察) の変化を調べた. また, 高速カメラの設定条件については，シャッタースピード $1 / 2000 \mathrm{sec}$, フレームレート500fps とした. その結果を 図 11 に示す.

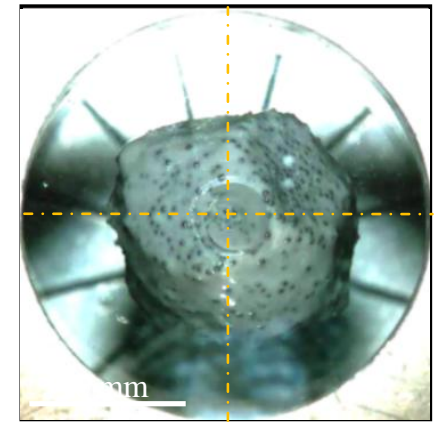

(a) $t=0 \mathrm{~s}, \Delta n=7.75 \mathrm{~mm}$

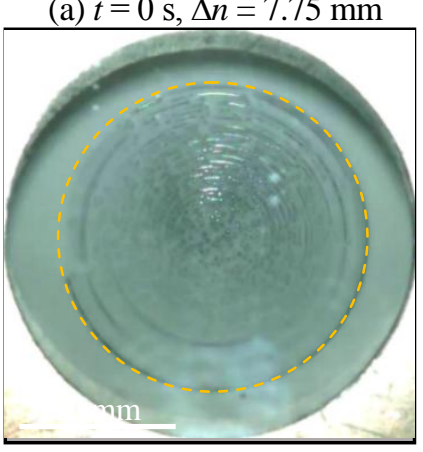

(f) $t=30.0 \mathrm{~s}, \Delta n=1.0 \mathrm{~mm}$



(b) $t=5.0 \mathrm{~s}, \Delta n=6.4$


Time (s)


(e) $t=23.0 \mathrm{~s}, \Delta n=1.0 \mathrm{~mm}$



(d) $t=20.0 \mathrm{~s}, \Delta n=2.05 \mathrm{~mm}$

Fig. 11 Photographs of steel ball brush obtained by high-speed camera and force sensor. 
図 11 中央のモーショングラフと各ビデオ画像より, 市販磁性研磨ペーストの場合と異なり（図 5 参照), (I) の領域が無くなり，（II）のブラシ接触面積が時間とともに増加する領域と（III）の接触領域が一定となる領域の 2 つの領域になる. 不規則形状の鉄粉を球形に変えたことによりブラシ接触状態の不均一が改善され, 磁気研磨 ブラシの中心から接触がスタートしたため領域（I）が無くなったものと考えられる．また，ビデオ画像より全領 域において，鋼球磁気研磨ブラシの接触は円形に一様に分布していることが分かる．そのため，モーショングラ フの変化も滑らかであり，縦方向の線幅も狭くなった．また，領域（II）において接触面積の増大につれて磁気 研磨ブラシの押付け力も増大寸る傾向や接触領域が一定值に収束しても増加を続ける傾向，領域（III）でギャッ プが $\Delta n=1.0 \mathrm{~mm}$ （設定ギャップ）となるときに最大值を取る（図 11(e)）ことなどは市販磁気研磨ブラシの場合 と同様である。しかし，送りが停止すると同時に押付け力は急速に減少して定常值に収束しており，定常值も非 常に小さくなっている．そこで，加工物を黄銅板（直径 $\Phi 30 \mathrm{~mm}$ ，厚さ $5 \mathrm{~mm}$ ）に交換して，上記と同じ加工条件 でアプローチ実験を行い，その時の押付け力の変化を動力計により詳細に計測した。 その結果を図 12 に示す.

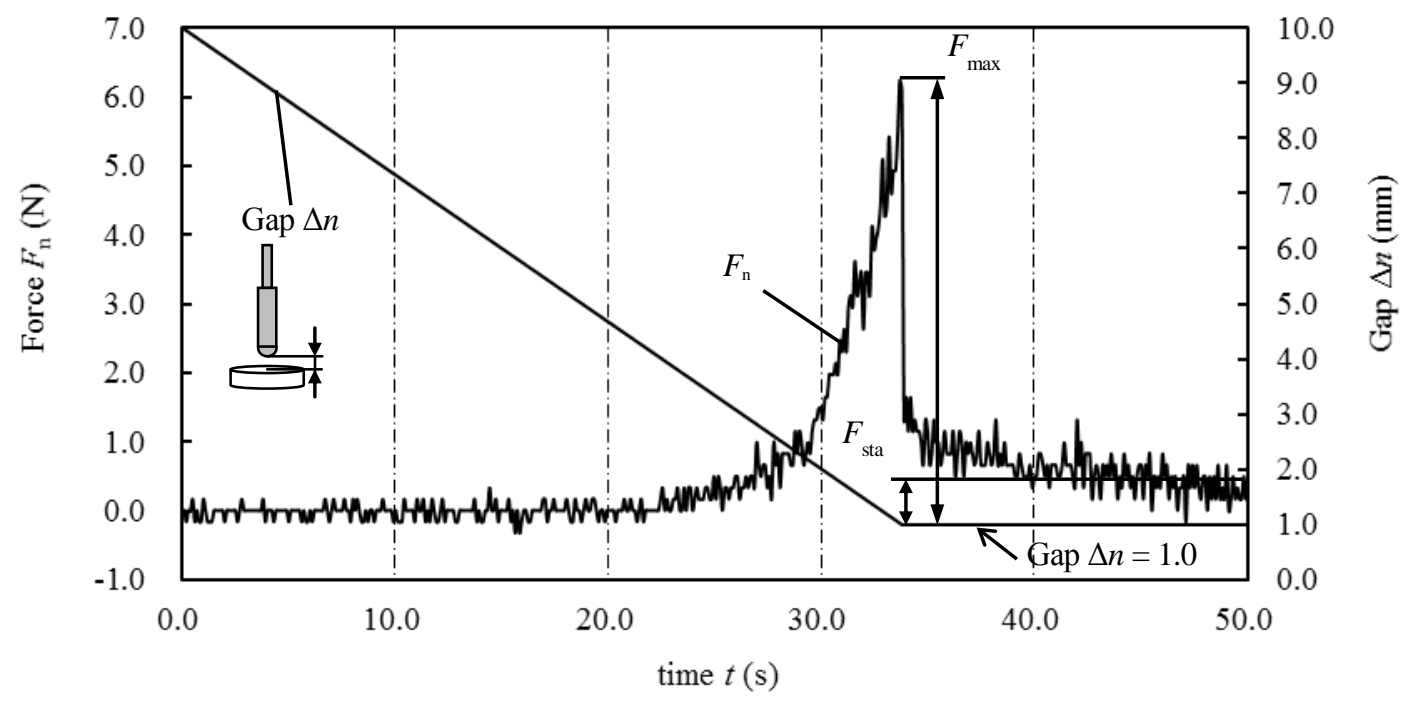

Fig. 12 Variation of pressing force of steel balls brush and Gap.

図 12 より,鋼球磁気研磨ブラシの最大押付け力 $F_{\max }=6 \mathrm{~N}$ は市販磁気研磨ブラシ $(30 \mathrm{~N})$ の約 5 分の 1 と小さく, 定常押付け力 $F_{\mathrm{sta}}=0.5 \mathrm{~N}$ は市販磁気研磨ブラシ $(15 \mathrm{~N})$ の約 30 分の 1 と非常に小さくなることが分かる. 磁気研 磨ブラシはアプローチ中に工作物によりブラシ形状が変形（塑性的）させられるが，このときに磁気研磨ブラシ を構成する鉄粉の配列が変化する，鋼球磁気研磨ブラシでは，鋼球同士の配列は相対的な滑りのみで変化できる ため, 磁力により生じる摩擦力に相当寸る力のみがブラシの最大押付け力になると考えられる. しかし，凹凸の 大きな市販磁気研磨ブラシ中の鉄粉の場合, 凹凸を乗り越えるための力も必要となるため, 最大押付け力が大き くなったものと考えられる. また鋼球磁気研磨ブラシの場合, アプローチが終了しブラシ形状の変形が停止した 時点で，鋼球は凹凸が無く相対移動が容易なため，ほとんどの鋼球が安定な状態に配列を完了しており，定常押 付け力としては静摩擦力のみとなるため非常に小さくなったものと考えられる. 一方, 市販磁気研磨ブラシ中の 鉄粉は凹凸が障害となり相対的な移動が困難なため, ブラシ形状の変形が停止しても，凹凸を乗越える途中の鉄 粉が多くを占めて安定な状態に配列が終了しないため定常押付け力が大きくなったものと考えられる.

さらに, 磁気研磨ブラシの粘弹性的な特性を調べるために, 設定ギャップまでの送り速度を変化させ，押付け 力の最大值 $F_{\max }$ と定常值 $F_{\mathrm{sta}}$ の変化を比較した。 実験条件は, アプローチ送り速度 $f_{\mathrm{n}}=3.6,10.8,18.0,24.0,90.0$ $\mathrm{mm} / \mathrm{min}$ でアプローチ実験した．実験結果をそれぞれ図 13，14 に示す

図 13，14より，両ブラシともアプローチ送り速度 $f_{\mathrm{n}}$ に対して定性的には同様の傾向を示寸ことがわかる. しか し, 押付け力の最大值 $F_{\text {max }}$ は鋼球磁気研磨ブラシでは市販磁気研磨ブラシの約 5 分の 1 , 定常值 $F_{\text {sta }}$ は市販磁気 研磨ブラシの約 30 分の 1 と小さい值となっていることがわかる. 


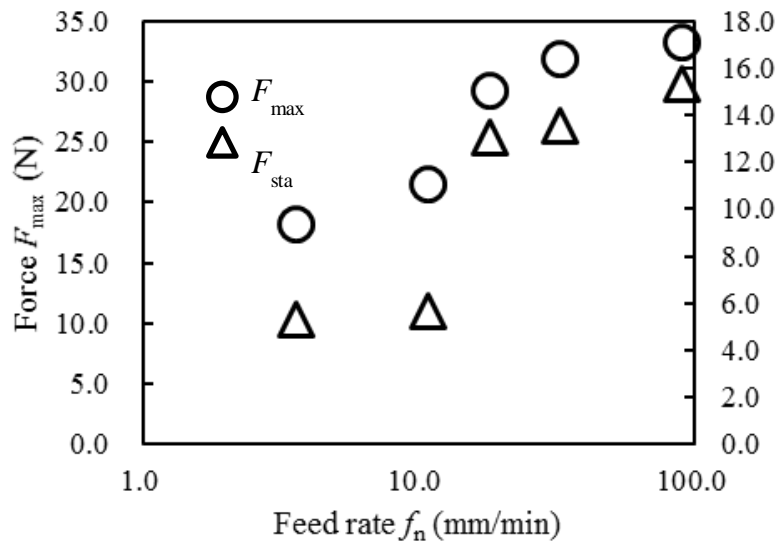

Fig. 13 Relationship between force $F$ and feed rate $f_{z}$ by commercial paste (gap $\Delta n=0.3 \mathrm{~mm})$.

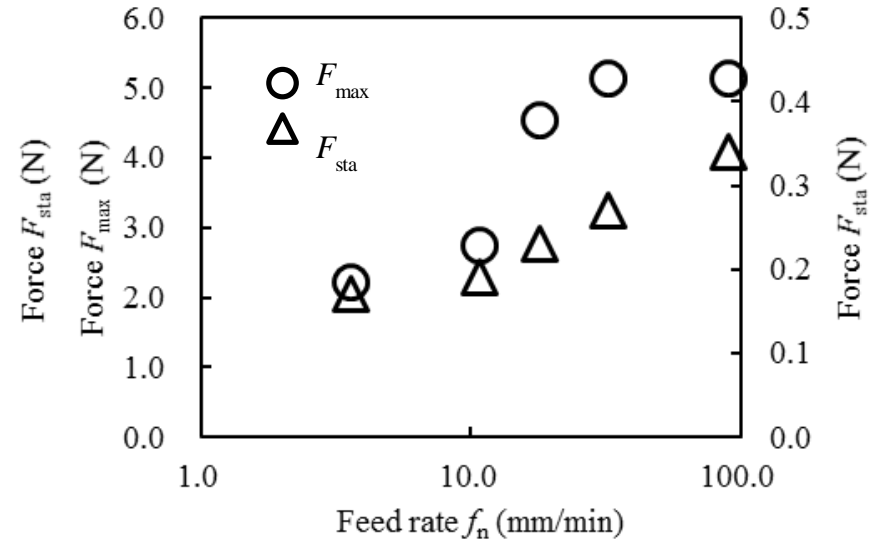

Fig. 14 Relationship between force $F$ and feed rate $f_{\mathrm{z}}$ by steel-balls paste (gap $\Delta n=1.0 \mathrm{~mm}$ ).

\section{$5 \cdot 3$ 市販磁気研磨ブラシと鋼球磁気研磨ブラシの研磨圧力の比較}

研磨においては研磨圧力が重要な最終指標と考えられる. そこで, 図 5 や図 11 で取得したモーショングラフの 動画の各画像とその時に同時取得した押付け力を用いてブラシの見掛けの接触面積（近似值）を求め，押付け圧 力を計算した. その結果を図 15,16 に示す. 両図より, アプローチ時の押付け圧力の最大值は市販磁気研磨ブラ

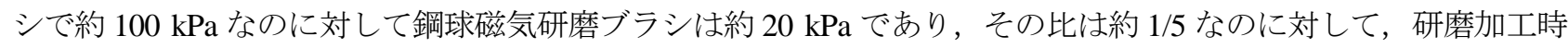
の押付け圧力となる定常時の押付け圧力は, 市販磁気研磨ブラシが約 $50 \mathrm{kPa}$ なのに対して鋼球磁気研磨ブラシで は約 $1 \mathrm{kPa}$ であり，その比は約 $1 / 50$ とかなり小さくなることがわかる. 以上の実験結果より, 磁気研磨ブラシの 種類(鉄粉の形状)や大きさの違いにより本磁気研磨ブラシでの押付け圧力は広範囲に変化することが分かった. これは，磁気研磨ブラシにおいて鉄粉の形状と大きさを適当に調整することにより，任意の押付け圧力に制御で きる可能性を示唆しており, 荒加工用と仕上げ加工用, 材料別などの用途に合わせた磁性研磨ペーストの設計手 法確立への可能性を見出すことができた.



Fig. 15 Variation of the pressure $P_{\mathrm{a}}$ with time by commercial paste.

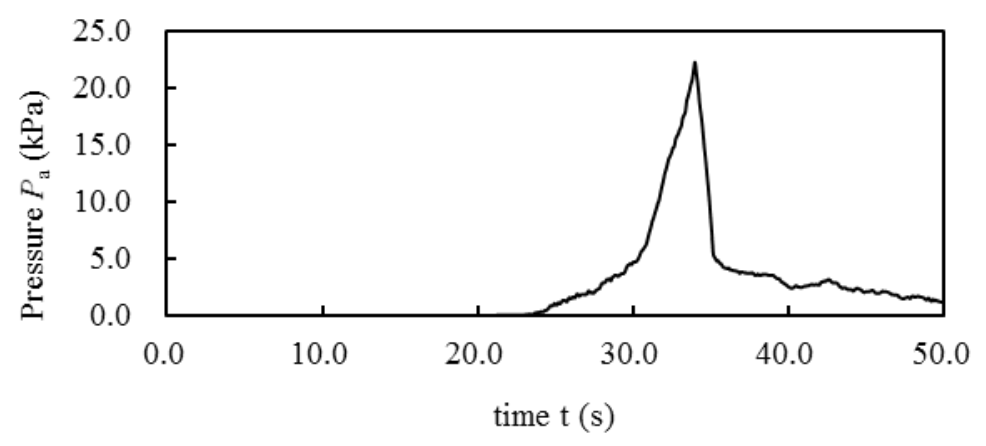

Fig. 16 Variation of the pressure $P_{\mathrm{a}}$ with time bysteel-balls paste. 


\section{6. 結 言}

本実験で，製作した磁気研磨実験専用ジグを用い，高速度ビデオ観察とそのモーショングラフ解析に基づく観 察手法を利用して, 磁気研磨ブラシの特性と押付け力の発生機構を実験的に検討した結果, 以下の結論を得た.

（1）市販磁性研磨ペーストを用いて加工メカニズムを検討した結果，鉄粒子による切削加工とアルミナによる 研磨加工の複合加工であると考えられる. このため, 高能率な鏡面仕上げ加工が実現されたものと考えられる.

（2）市販磁性研磨ペースト中の鉄粒子が不規則で凹凸の大きい形状のため，加工面内で磁気研磨ブラシが均一 に分散せず，形状精度の維持および加工面の欠陥の回避が困難であったと考えられる.

（3）本磁気研磨工具による研磨加工においては，磁性体（鉄粉）の形状および大きさが押付け圧力に大きく影 響し，これらを変えることで押付け圧力を広範囲に制御できる可能性を見出した.

（4）本磁気研磨加工法では，アプローチ条件の設定に十分な配慮が必要で，非常に高い押付け圧力により形状 精度を悪化させる原因となる.

\section{文献}

古木辰也，馬雷，廣垣俊樹，青山栄一，小川圭二，マシニングセンタ上での磁気研磨加工とエンドミル加工によ る魔鏡面の創製，日本機械学会論文集，Vol.80, No.820 (2014), DOI: 10.1299/transjsme.2014dsm0390.

Jayakumar, P., Ray, S. and Radhakrishnan, V., Optimising progress parameters of magnetic abrasive machining to reduce the surface roughness value, Journal of Spacecraft Technology, Vol.7 (1997) pp.58-64.

川久保英樹，土屋和博，孫運海，手塚佳夫，三木一隆，山崎隆夫，単純混合型磁性研磨材の研磨性能に関寸る研 究，日本機械学会論文集 C 編，Vol.65, No.632 (1999), pp.1690-1697.

川久保英樹，佐藤運海，村田修一，スラリ一吐出式磁気研磨工具の研磨性能に関する研究一非磁性加工物の仕上 げ特性，砥粒加工学会，Vol.58, No.1 (2014), pp.247-252.

河西敏雄，安永暢男，高付加価值のための精密研磨，日刊工業新聞社(2010), p.135.

Li, W.H., Yang, S.Q. and Li, X.H., Mechanism research of viscoelastic magnetic abrasive tools finishing, Computer Modelling and New Technologies, Vol.17 (2013) pp.121-129.

夏目勝之, 進村武男, 平面磁気研磨法の加工機構に関寸る研究 (垂直方向押付け力特性の解明), 日本機械学会論 文集 C 編, Vol.74, No.737 (2008), pp.212-218.

進村武男, 高沢孝哉, 波田野栄十, 磁気研磨法の研究（第 1 報）加工原理と二，三の研磨特性，精密工学会誌， Vol.52, No.5 (1986), pp.851-857.

Sharma, V., Verma, G.C.and Pandey, P.M., Magnetic Abrasive Finishing Process: State of the Art, Vol.10, No.35 (2015), pp. $27601-27607$.

土屋和博，清水保雄，榊和彦，佐藤元太郎，磁気研磨法における研磨機構，日本金属学会誌，Vol.57, No.11(1993), pp.1333-1338.

\section{References}

Furuki, T., Ma, L.,Hirogaki, T., Aoyama, E. and Ogawa, K., Fabrication of magic-mirror with magnetic polishing and end-milling on machining center, Transactions of the JSME(in Japanese), Vol.80, No.820 (2014), DOI: 10.1299/transjsme.2014dsm0390.

Jayakumar, P., Ray, S. and Radhakrishnan, V., Optimising progress parameters of magnetic abrasive machining to reduce the surface roughness value, Journal of Spacecraft Technology, Vol.7 (1997) pp.58-64.

Kawakubo, H., Tsuchiya, K., Sun, Y., Tezuka, Y., Miki, K. and Yamazaki,T., Study on polishing characteristics of simply mixed oil bonded magnetic abrasives,Transactions of the Japan Society of Mechanical Engineers,Series C, Vol.65, No.632 (1999), pp.1690-1697 (in Japanese).

Kawakubo, H.,Sato, U. and Murata, S., Study on polishing performance of slurry discharge type magnetic polishing tool finishing characteristics of non-ferromagnetic materials, Journal of the Japan Society for Abrasive Technology, Vol.58, No.4 (2014), pp.247-252(in Japanese).

Kasai, T. and Yasunaga, N., Precision polishing for High Added Value (2010), p.135, Japan Industrial Publishing (in Japanese).

Li, W.H., Yang, S.Q. and Li, X.H., Mechanism research of viscoelastic magnetic abrasive tools finishing, Computer 
Modelling and New Technologies, Vol.17 (2013) pp.121-129.

Natsume, M. and Shinmura, T., Study on the mechanism of plain magnetic abrasive finishing process (Elucidation of Normal Force Characteristics), Transactions of the Japan Society of Mechanical Engineers, Series C, Vol.74, No.737 (2008), pp. 212-218 (in Japanese).

Shinmura, T., Takanawa, K. and Hatano K., Study on magnetic-abrasive finishing (1 st report) on process principle and a few finishing characteristics, Journal of the Japan Society for Precision Engineering, Vol.52, No.5 (1986), pp.851-857 (in Japanese).

Sharma, V., Verma, G.C. and Pandey, P. M., Magnetic Abrasive Finishing Process: State of the Art, Vol.10, No.35 (2015), pp. $27601-27607$.

Tsuchiya. K., Shimizu. Y., Sakaki, K. and Sato. M., Polishing mechanism of magnetic abrasion, Japan Institute of Metals and Materials,Vol.57, No.11 (1993), pp.1333-1338. 